\title{
Developments in Household Debt in Eighth District MSAs
}

Don Schlagenhauf, Economist

James D. Eubanks, Senior Research Associate

T he Great Recession underscored the implications of high household debt. In the early 2000s, the housing sector played an important role in the growing economy. The homeownership rate increased to record levels due to easy access to mortgage credit. Unfortunately, many households went into foreclosure when they could not sustain the high debt levels.

Recently, total nominal household debt for the United States passed its pre-recession peak, which leads to the question of whether another debt crisis is on the horizon. In this essay, we compare the patterns in household debt today with the patterns prior to the Great Recession and focus on the four largest metropolitan statistical areas (MSAs) in the Eighth Federal Reserve District: Little Rock, Louisville, Memphis, and St. Louis. ${ }^{1}$

\section{Current household-debt levels indicate little likelihood of a debt crisis.}

We find that, although debt levels are rising, low delinquency rates and a shift in the composition of household debt indicates that the likelihood of a debt crisis is small.

\section{Debt and the Eighth District MSAs}

The figure shows the year-over-year growth rate of total debt for each MSA for the period 2007-18. The growth rate is similar across MSAs: Over the past year, the rate was 1.5 percent in Memphis and St. Louis, 1.7 percent in Little Rock, and 2.3 in Louisville. In all four MSAs, total debt is growing more slowly than in the lead up to the Great Recession. Between the first quarter of 2004 and the first quarter of 2008, the average year-over-year growth rate was above 4 percent for each MSA.

Table 1 summarizes the data for each MSA and each of the debt categories over the past four quarters.

One key difference between the pre-recession years and today is mortgage debt. In all four MSAs, mortgage debt

\section{Total Real Consumer Debt}

Year-Over-Year Percent Change

$$
8
$$

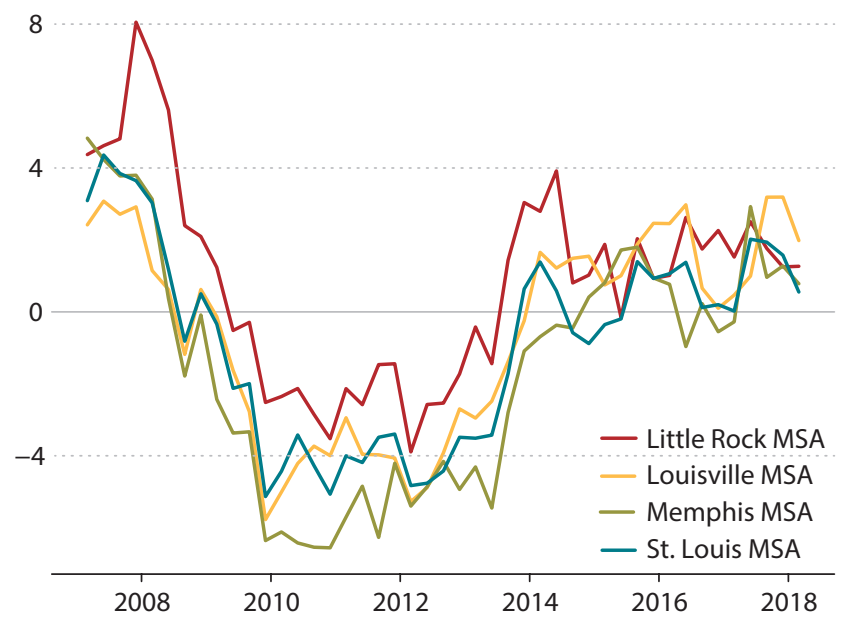

SOURCE: Federal Reserve Bank of New York/Equifax Consumer Credit Panel.

grew by an average year-over-year rate of less than 2.0 percent over the past four quarters. This is a much slower growth rate than that observed prior to the 2008 recession. In 2004, the rate was 8.5 percent in Memphis and 13.0 percent in St. Louis. Over the past four quarters, home equity line of credit (HELOC) debt declined by an average yearover-year rate of 2.5 percent in Little Rock, 5.5 percent in Memphis, and 5.1 percent in St. Louis but increased slightly in Louisville. From 2004 to the start of the recession, however, HELOC debt grew at an average year-over-year rate of 24.3 percent in Louisville, 37.0 percent in Memphis, 45.7 percent in Little Rock, and 52.1 percent in St. Louis.

Unlike mortgage and HELOC debt, credit card debt has grown at a faster year-over-year rate in recent years than in the years prior to the recession. In 2007, credit card debt grew slightly in Louisville and St. Louis and fell in Little Rock and Memphis. Over the past four quarters, though, the rate has grown by 3.1 percent in St. Louis, 3.9 percent in Louisville, 4.7 percent in Memphis, and 4.9 percent in Little Rock. 
Table 1

Year-Over-Year Percentage Change in Real Consumer Debt for MSAs Over the Past Four Quarters

\begin{tabular}{|c|c|c|c|c|}
\hline Debt type & 2018:Q1 & 2017:Q4 & 2017:Q3 & 2017:Q2 \\
\hline \multicolumn{5}{|c|}{ Little Rock MSA } \\
\hline Mortgage & 0.8 & 0.5 & 1.4 & 1.9 \\
\hline HELOC & 1.2 & 4.2 & -4.5 & -11.1 \\
\hline Auto & 2.5 & 2.4 & 2.1 & 4.4 \\
\hline Credit card & 3.6 & 4.2 & 5.4 & 6.5 \\
\hline \multicolumn{5}{|c|}{ Louisville MSA } \\
\hline Mortgage & 0.9 & 2.7 & 2.8 & 0.0 \\
\hline HELOC & 4.4 & 1.1 & -0.6 & -1.6 \\
\hline Auto & 5.0 & 5.8 & 5.8 & 6.9 \\
\hline Credit Card & 3.9 & 3.6 & 4.4 & 3.7 \\
\hline \multicolumn{5}{|c|}{ Memphis MSA } \\
\hline Mortgage & 0.9 & 1.2 & 0.0 & 2.4 \\
\hline HELOC & -6.5 & -4.6 & -6.6 & -4.3 \\
\hline Auto & 2.1 & 3.0 & 4.1 & 6.2 \\
\hline Credit card & 3.9 & 4.6 & 4.8 & 5.3 \\
\hline \multicolumn{5}{|c|}{ St. Louis MSA } \\
\hline Mortgage & -0.1 & 1.0 & 1.4 & 1.3 \\
\hline HELOC & -3.2 & -5.0 & -6.9 & -5.2 \\
\hline Auto & 1.8 & 3.9 & 4.9 & 5.7 \\
\hline Credit card & 2.7 & 3.6 & 3.3 & 2.8 \\
\hline
\end{tabular}

SOURCE: Federal Reserve Bank of New York /Equifax Consumer Credit Panel.

Auto debt has been a focus of much concern. In all four MSAs, auto debt has far surpassed its peak level before the recession. Auto debt grew at high rates during 2014 and 2015 but has since slowed. Over the past four quarters, the average year-over-year growth rates in the four MSAs were between 2.9 and 5.9 percent. In contrast, the growth rates were all above 8 percent in 2015-higher than before the recession.

\section{Any Indications a Debt Crisis Is Brewing?}

The recent high growth rate of auto debt has led the popular press to wonder whether another debt crisis is brewing. However, the burden of auto debt is much smaller
Table 2

Year-Over-Year Percentage Change in Serious Delinquency Rates for MSAs, 2018:Q1

\begin{tabular}{lcccc} 
Debt type & Little Rock & Louisville & Memphis & St. Louis \\
\hline Mortgage & -0.2 & -0.4 & -0.4 & -0.1 \\
\hline HELOC & 0.1 & -0.2 & -0.3 & -0.6 \\
\hline Auto & 0.5 & 0.7 & 0.3 & 0.4 \\
\hline Credit card & 1.5 & 0.5 & 0.4 & -0.2
\end{tabular}

SOURCE: Federal Reserve Bank of New York /Equifax Consumer Credit Panel.

compared with mortgage debt. Growing debt is only a problem if it cannot be paid off. One way to see if concern is warranted is to examine serious delinquency rates (for payments 90 days or more past due). An increase in these rates could signal trouble. Table 2 shows the year-over-year percentage change in serious delinquency rates for 2018:Q1 for the four debt categories: The rates for mortgage and HELOC debt generally declined, while those for credit card debt and auto debt increased slightly.

Although serious delinquency rates for auto and credit card debt increased, it is too early to determine whether a debt crisis is imminent. The rates for credit card debt remain well below their recession peaks. The rates for auto debt have returned to or surpassed their recession peaks in Little Rock and Louisville; but in Memphis, St. Louis, and the United States overall, they remain well below their recession peaks.

\section{Summary}

Growth in household debt, a major contributing factor to the Great Recession, has led many to worry that a debt crisis is on the horizon. Although the levels of certain types of debt are rising in the MSAs of the Eighth Federal Reserve District, serious delinquency rates have not yet reached alarming levels.

\section{Note}

1 We exclude student debt because of inconsistencies in reporting. We adjust debt levels for inflation using the personal consumption expenditures chaintype price index. 